\title{
The structure of eusocial bee assemblages in Brazil
}

\author{
Jacobus C. BIESMEIJER, E. Judith SLAA \\ Institute of Integrative and Comparative Biology, University of Leeds, Leeds LS2 9JT, UK
}

Received 5 October 2005 - revised 29 December 2005 - accepted 17 January 2006

\begin{abstract}
Social bee - food plant relationships have been studied extensively, especially in the Neotropics. This is, however, the first quantitative comparison and review of a large set (28) of studies. Patterns in social bee richness, niche breadth and associations between social bee taxa could be explained partly by species-specific differences in behaviour, foraging traits and response to interspecific competition. Bee assemblages contain higher percentages of social Apidae towards the equator. Medium-sized non-aggressive group foragers had the narrowest diet and the super-generalists the broadest diet. Niche breadth generally decreased with the number of social bee species in the assemblage indicating that interspecific competition influences diet choice. Cluster-analysis revealed two main groups in terms of food plant use: medium-sized non-aggressive group foragers and a group containing the aggressive group forager Trigona spinipes, the honeybee and three small scramblers. Four other taxa were not associated with any other taxa.
\end{abstract}

community ecology / stingless bees / competition / niche partitioning / Meliponini / Apidae

\section{INTRODUCTION}

Bees are the main flower visitors and pollinators in the majority of the world's ecosystems and the diversity of their relations with flowers has been documented extensively for both temperate and tropical regions (e.g. Roubik, 1989; Barth, 1991; Kevan and Imperatriz-Fonseca, 2002). Various guilds of bees can be distinguished based on bee-plant relationships, e.g. buzz-pollinators, oil gathering bees, nectar robbers, which are useful in the analysis of plant-pollinator community structure (e.g. Roubik, 1979, 1989, 1992). Because of the large numbers of bees and the wide variety in flower use, community-wide analyses necessarily lump bees into larger groups (Roubik, 1989). In such analyses, the highly-social bees tend to appear as a single or a few separate clusters: honeybees, bumblebees and in tropical studies stingless bees (sometimes separated into Trigona s.l. and Melipona). These social bees differ from most

Corresponding author: J.C. Biesmeijer, j.c.biesmeijer@leeds.ac.uk solitary bees, among other traits, in that they are obligate generalists in food choice because their colonies outlast the flowering season of single plant species. Not all social bees are the same, however. Differences in tongue length are, for example, a major factor in niche partitioning in relation to flower choice among temperate bumblebees (Morse, 1982; Harder, 1985 ) and seem to be associated with flower visitation in Asian stingless bees (Nagamitsu and Inoue, 2005).

In the tropics, the majority of the eusocial bees are stingless bees (Roubik, 1989, 1992; Heithaus, 1979b), but they also include honeybees (various species in Asia, Apis mellifera in Africa and America) and bumblebees (mainly at higher altitudes, but also common in lowland Brazil). These groups all use a wide range of plant species for nectar and pollen collection. In addition, many studies have shown that eusocial bees differ among each other in the pollen and nectar sources they use. Social bee food plant interactions have been studied in many areas by means of analysis of pollen collected from returning foragers or pollen stores in the nest (Neotropical 
Table I. Overview of the studies used in this meta-analysis. State: BA = Bahia, MA = Maranhao, MG = Minas Gerais, RS = Rio Grande do Sul; SP = São Paulo. Sampling: $d=$ day, $m=$ month, $y=$ year. Numbers of bees and food plants reported are given in the last two columns.

\begin{tabular}{|c|c|c|c|c|c|c|}
\hline Author & Year & State & Habitat & Sampling & Bees & Plants \\
\hline 1. Wilms & 1995 & SP & Atlantic Rain forest & 3 y; biweekly & 21 & 230 \\
\hline 2. Sofia & 1996 & SP & Urban park & $1 \mathrm{y}$; biweekly & 27 & 106 \\
\hline 3. Sofia & 1997 & SP & Urban park & 1 y; biweekly & 14 & 93 \\
\hline 4. Silveira & 1989 & MG & Dry woodland (Cerrado) & $1 \mathrm{y}$; monthly $3-5 \mathrm{~d}$ & 22 & 106 \\
\hline 5. Mateus & 1998 & SP & Dry woodland (Cerrado) & 2 y; biweekly & 25 & 73 \\
\hline 6. Hoffmann & 1990 & RS & Fields + subtropical forest & 2 y; biweekly & 6 & 108 \\
\hline 7. Carvalho & 1990 & MG & Dry woodland (Cerrado) & 1 y; biweekly & 13 & 75 \\
\hline 8. Campos & 1989 & SP & Dry woodland (Cerrado) & 3 y; weekly & 12 & 39 \\
\hline 9. Silva & 1998 & Paraiba & Dunes (Restinga) & 1 y; biweekly & 2 & 29 \\
\hline 10. Aguilar & 1998 & SP & Atlantic Rain forest & $15 \mathrm{~m}$; biweekly & 18 & 96 \\
\hline 11. Pedro & 1992 & SP & Dry woodland (Cerrado) & 1 y; biweekly & 22 & 139 \\
\hline 12. Knoll & 1990 & SP & Urban park & $1 \mathrm{y} ;$ every $10 \mathrm{~d}$ & 12 & 154 \\
\hline 13. Castro & 2001 & BA & Semi-arid (Caatinga) & $1 \mathrm{y} ;$ monthly & 10 & 101 \\
\hline 14. Martins & 1990 & BA & Semi-arid (Caatinga) & 1 y; biweekly & 9 & 39 \\
\hline 15. Martins & 1990 & BA & Dry woodland (Cerrado) & 1 y; biweekly & 10 & 81 \\
\hline 16. Ramalho & 1995 & SP & Atlantic Rain forest & $1.5 \mathrm{y}$; weekly & 20 & 106 \\
\hline 17. Rego & 1998 & MA & Dry woodland (Cerrado) & $1 \mathrm{y}$; every month $2 \mathrm{~d}$ & 22 & 33 \\
\hline 18. Alves dos S & 1996 & RS & Subtropical Rain forest & $8 \mathrm{~m}$; biweekly $4 \mathrm{~d}$ & 15 & 113 \\
\hline 19. Schlindwein & 1995 & RS & Shrubland & 5 y; Sept-May & 9 & 131 \\
\hline 20. Viana & 1999 & BA & Dunes (Restinga) & $1 \mathrm{y} ;$ every $10 \mathrm{~d}$ & 6 & 48 \\
\hline 21. Barbola & 1993 & Parana & Open fields and various & $1 \mathrm{y} ;$ every $10 \mathrm{~d}$ & 9 & 60 \\
\hline 22. Faria & 1994 & MG & Rupestrian fields & $1 \mathrm{y} ;$ monthly $1 \mathrm{~d}$ & 10 & 38 \\
\hline 23. Harter & 1999 & RS & Araucaria forest & $3 \mathrm{y} ; 295 \mathrm{~d}$ total, summer & 14 & 185 \\
\hline 24. Taura & 1990 & Parana & Urban park & $1 \mathrm{y}$; weekly & 7 & 93 \\
\hline 25. Viana & Unpubl. & BA & Dunes (Restinga) & $1 \mathrm{y} ;$ monthly? & 8 & 35 \\
\hline 26. Castro & Unpubl. & BA & Atlantic rain forest & $1 \mathrm{y}$; monthly? & 6 & 40 \\
\hline 27. Castro & Unpubl. & BA & Orchards & $1 \mathrm{y}$; monthly? & 17 & 20 \\
\hline 28. Cortopassi-Laurino & 1982 & SP & Urban park & 2 y; biweekly & 11 & 190 \\
\hline
\end{tabular}

studies reviewed by Ramalho et al., 1990; Wilms and Wiechers, 1997; Nagamitsu et al., 1999; Nagamitsu and Inoue, 2002) and by means of direct observation on flowers (e.g. studies in Tab. I; Roubik, 1979, 1989).

Few attempts have been made to compare the foraging ecology of eusocial bees across studies. These comparative studies either simply list the major food plants for various taxa (Ramalho et al., 1990) or draw broad conclusions across all bees (Roubik, 1989). Given the large number of detailed studies of social bee - food plant interaction, it is surprising that no quantitative comparisons are available. Such a comparison could elucidate fundamental rules governing community richness and the structure of social bee assemblages. The findings could then be related to new information on the communication systems (e.g. Nieh, 2004; Biesmeijer and Slaa, 2004; Aguilar et al., 2005; Jarau et al., 2003), aggressive behaviour at food sources (Nagamitsu and Inoue, 1997; Slaa et al., 2003), the sugar concentration of the nectar they collect (Roubik et al., 1995; Biesmeijer et al., 1999a, b), and flower constancy (Slaa et al., 1998, 2003).

The aim of this paper is to search for general trends in tropical eusocial bee food plant relationships and to relate trends in food plant use to foraging ecology and behaviour. We restrict ourselves to Brazilian studies of social bee flower visitation in which bees were collected for an extended period in a well-defined area. The reason 


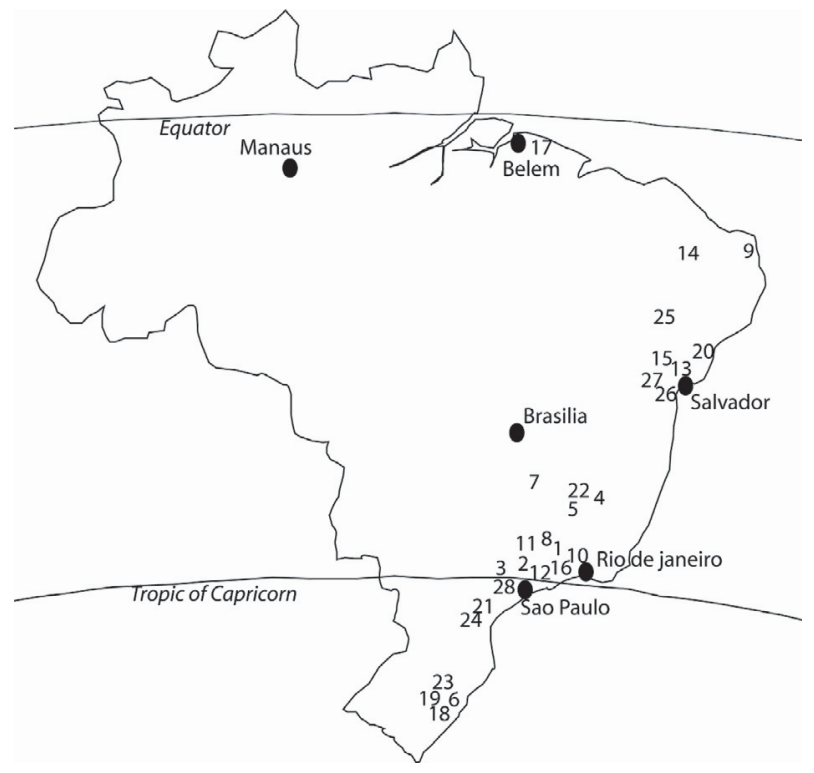

Figure 1. Layout of the study location in Brazil. Numbers refer to the studies listed in Table I.

Table II. Thesis not included in the meta-analysis and reasons for exclusion.

\begin{tabular}{ll}
\hline Study & Reason for exclusion \\
\hline 1. Aguiar (2001) & No systematic data about visited plants \\
2. Kaminski (2001) & Visitors of only three plant species \\
3. Laroca (1974) & No list of visited plants per bee species (lumped per bee and plant family) \\
4. Orth (1983) & No list of visited plants per bee species (lumped per bee genus) \\
5. Machado (2002) & No systematic data about visited plants \\
6. Zanella (1991) & No list of visited plants per bee species (lumped per bee and plant family) \\
7. Schwartz Filho (1993) & No list of visited plants per bee species (lumped per bee and plant family) \\
8. Hakim (1983) & No list of visited plants per bee species (lumped per bee and plant family) \\
9. Albuquerque (1998) & No eusocial bees found on flowers (only Apis mellifera) \\
10. Knoll (1985) & Only data on visits by one species (Tetragonisca angustula) \\
11. Antonini (2002) & Only data on visits by one species (Melipona quadrifasciata) \\
12. Castro (1994) & Same data as Martins (1990) (\#14) \\
13. Viana (1992) & Same data as Martins (1990) (\#15) \\
14. All palynological studies & Analysed pollen grains from incoming bees or from pollen pots. \\
& Studies reviewed by Ramalho et al., 1990. \\
\hline
\end{tabular}

for selecting these studies is that they all use very similar methodology (see methods section) while representing a wide variety of (sub-)tropical habitats including rain forest, tropical savannas, dunes, grasslands and anthropogenic habitats (Tab. I; Fig. 1). Many other Brazilian studies could not be included because methodology was very different, e.g. palynological work (Kleinert-Giovannini and Imperatriz-Fonseca, 1987; Ramalho et al.,
1990 and references therein) or because single bee or plant species were studied (Tab. II).

The main questions we are addressing here are:

(1) What are the ecological correlates of eusocial bee richness?

(2) Are all social bees equally generalist in their food plant use? 
(3) Can we find general patterns of association among the social bees by comparing their food plant use across studies?

\section{METHODS FOR COMPARISON OF STUDIES}

\subsection{Study selection and databasing}

To provide consistency in the analysis, we used sources that provided bee-plant interaction tables and then performed all analyses based on the published tables (Tab. I). Following Gates' (2002) recommendation, we include a list of the studies that we reviewed but that are not included in the analysis and the reasons for excluding these studies (Tab. II).

The datasets were selected according to the following criteria:

(1) Studies had to be taxonomically well resolved. The two leading Brazilian social bee experts, Profs Padre Santiago Moure and João Camargo, identified bees in most studies and plants were identified by various leading botanical taxonomists;

(2) Exhaustive sampling of a restricted area. All studies collected at least once a month for a year, but many sampled more intensively (Tab. I). Study areas ranged from 0.3 ha to more than $200 \mathrm{ha}$, and was $<100$ ha in all but three studies;

(3) Unrestricted sampling of bees and flowering plants. Note, however, than many studies under-sampled the higher strata of the forest;

(4) Comparable sampling methods. Methodology was highly uniform among the studies. All used the Sakagami et al. (1967) sampling method or a variant thereof. In this method transects are sampled with a fixed amount of time spent at each flowering plant (or patch). The sampling of transects is randomized in time, order, and direction;

(5) Availability of plant-bee interaction tables or raw data sheets. We compiled each data matrix from the interaction lists or raw data tables provided in the source. More than a dozen additional studies had to be excluded because they lacked detailed information of bee-plant interactions in the published material (Tab. II). A complete list of the main features of all studies included is given in Table I (see also Biesmeijer et al., 2005). Many datasets have been published only in student PhD- or MSc-theses, but all are publicly available from the respective universities.

During the data input process we stumbled upon several interpretation problems. In all cases we used the data from the raw tables. We recalculated ecological indices from the raw data matrices; therefore some of the values we obtained may differ slightly from the values given in the sources.

\subsection{Ecological indices and statistics}

For each study we calculated a set of ecological parameters, e.g. species richness, niche breadth, similarity in plant use, and a cluster-analysis based on food plant use. Thereafter, we compared these parameters across studies. Throughout, we followed recommendations of Krebs (1999) and Legendre and Legendre (1998).

To assess whether estimated species richness was similar to the number of social bee species reported, we generated species accumulation curves and three estimators (Fig. 2; Bootstrap, Jackknife, and Michaelis-Menten mean estimate) that are recommended as the best estimators for species richness (Colwell, 1997; Legendre and Legendre, 1998; Krebs, 1999) using the freeware application EstimateS (Colwell, 1997; http://viceroy.eeb.uconn.edu/). The curves were generated using 50 randomizations. In almost all cases the Michaelis-Menten and bootstrapped estimates are very close to the number of species reported. This shows that the social bee component had been sampled fairly completely. Therefore we use the reported numbers of bee species as the bee richness of the study sites.

Foraging niche breadth was measured by the Shannon-Wiener Index (Krebs, 1999). This index was highly correlated with the Simpson's index, but provided a wider range of values. To compare this function across studies, the index was standardized using the total number of plant species used by the social bees.

To assess similarity in plant use across bees we calculated the Sorensen Coefficient using presence/absence data (Legendre and Legendre, 1998). The similarity matrices were the basis of an average linkage clustering (UPGMA) performed with the R-Package for Multivariate and Spatial Analysis, version 4.0 d5 (Casgrain and Legendre, 2001; http://www.fas.umontreal.ca/BIOL/legendre). 


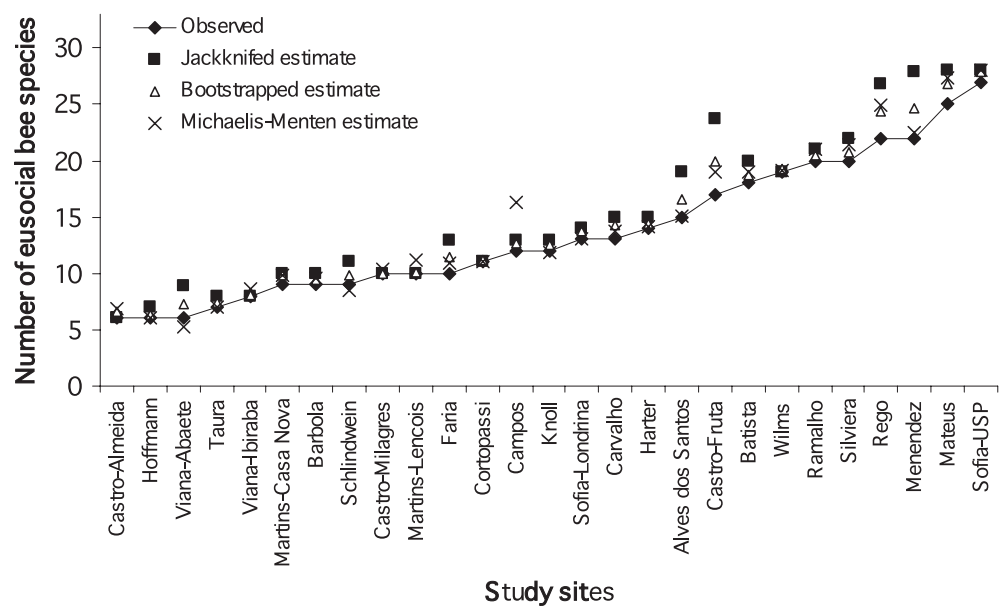

Figure 2. The observed number of eusocial Apidae and the estimated richness for all studies included in this paper. Studies are ordered from low to high observed richness. Richness was estimated using the EstimateS freeware version 7.5 (Colwell, 1997) and depicted are a bootstrapped and jackknifed estimates and the Michaelis Menten Mean estimate.

\subsection{Higher order clustering}

In absence of standard methods for comparing 30 large matrices, we devised the following procedure.

First, we had to standardize the bee taxa across studies. The cluster analyses of individual studies showed that the different members of the larger genera tended to group together except for Trigona and Plebeia. This led us to pool species for several common taxa (Melipona, Bombus, Frieseomelitta, Scaptotrigona, Partamona and Paratrigona). Other common genera were represented by a single taxon (Schwarziana quadripunctata, Apis mellifera, Tetragonisca angustula). Finally we used two common Trigona and one Plebeia species for a total of 13 taxa that occurred in most studies. Other rare genera were not included in the analysis, because they were limited to single habitats and few studies.

Second, we performed the same cluster-analysis as before (UPGMA clustering performed with the R-Package for Multivariate and Spatial Analysis, version 4.0 d5 (Casgrain and Legendre, 2001; http://www.fas.umontreal.ca/BIOL/legendre) for each study using only the 13 (pooled) taxa.

Third, we arbitrarily decided on two thresholds to allow us to separate between strong interactions (distance $\leq 0.5$ ), weak interactions (distance $\leq 0.7$ ) and no interactions (distance $>0.7$ ). We preferred this method over the alternative averaging distances over all studies, which would not give insight in how frequently taxa are associated (for example, distances $0,0,1,1$ would give the same average as four times 0.5 , but represents very different interactions).

Fourth, we calculated the percentage of possible interactions that were weak and strong interactions for all pair-wise combinations as well as the average for the 13 taxa. The matrix of pair-wise weak interactions was used to perform the acrossstudies cluster-analysis (see Fig. 7). We did not use the matrix of strong associations, because for some pair-wise combinations too few data were available. The average percentages of weak and strong associations per taxon were used for correlations with other ecological indices (see Fig. 8).

\section{WHAT ARE THE CORRELATES OF SOCIAL BEE RICHNESS?}

Highly-social bees make up a significant part of the tropical lowland bee assemblages (Roubik, 1989). Highest diversity seems to be found in lowland rain forest. For example, social Apidae (mostly stingless bees) represent $26 \%$ of all bees in Sumatra, 26\% in French Guiana, and about $18 \%$ in Belem, Brazil (Roubik, 1990, 1979; Ducke in Roubik, 1979). In dry forest and savanna habitats in Costa Rica, however, the Apidae (mostly stingless bees) make up only $12.5 \%$ of the species, 
but $55 \%$ of individuals (Heithaus, 1979a, b). The richness of the bee community varies greatly among habitats (e.g. Moldenke, 1975; Roubik, 1989) and representation of the different bee families changes with latitude (Roubik, 1989) and possibly altitude. Can we also detect such patterns among the Brazilian social bee assemblages?

Brazil spans most of South America from the Equatorial Amazon to the subtropical Araucaria forests and harbours dry and wet, natural and disturbed, lowland and middle elevation habitats, forests, woodlands and grasslands. There does not seem to be a general trend between the number of eusocial bees and latitude (Fig. 3a). The three (semi-)natural habitats tend to differ marginally in social Apidae richness (1-way ANOVA: $\mathrm{df}_{2,13}, \mathrm{~F}=3.60$, $P=0.057)$ with the semi-arid habitats being poorer $(11.5 \pm 4.8$ species $)$ than cerrado $(18.0 \pm 6.1)$ and rain forest $(19.7 \pm 1.5)$. A similar trend in species richness from wet to dry habitats has been reported by Roubik for Panama (1993).

The share of social Apidae in total bee richness ranges from about 3 to 26 percent. Towards the south, social bees are generally less prominent in the bee assemblages (Fig. 3b). However, the variation is very large between the equator and 20 degrees south. This trend is largely a result of increasing solitary bee richness towards the south (Pearson correlation: $\rho=0.59, P<0.05)$ and lower stingless bee richness in subtropical Brazil (see Fig. 3a).

Ecological theory predicts that habitats rich in resources can harbour relatively more species than poor habitats, i.e. have denser species packing. Heithaus (1979a) observed this trend for total bee diversity in three Costarican lowland habitats. We did not find this pattern for the Brazilian social Apidae. In contrast, the more food plant species the lower the species packing (Fig. 3c; Pearson correlation, $\rho=-0.53, P=0.004)$. This is presumably a result of the higher food plant richness in some habitats sampled more in the south (e.g. rain forest). However, differences in species packing cannot be explained by habitat differences (Kruskal-Wallis test with categories rain forest, cerrado, semi-arid, urban habitats: $\chi=5.3, P=0.15)$. It seems likely
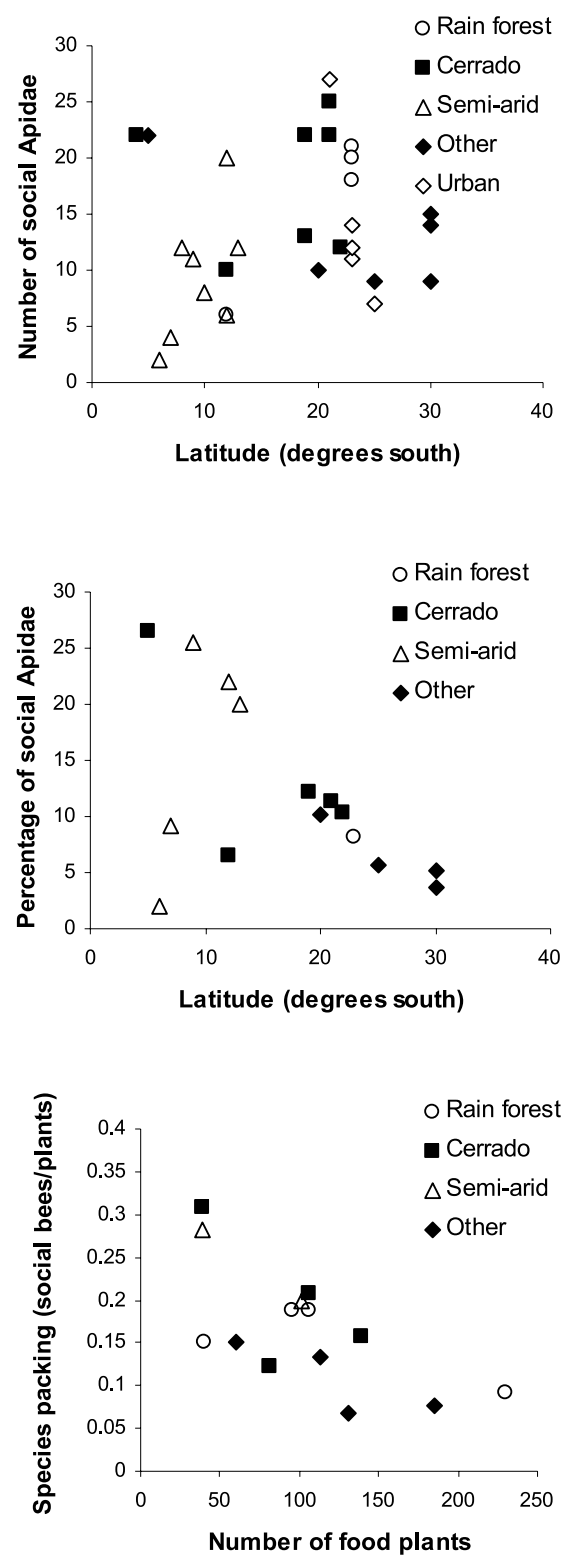

Figure 3. Correlations between the social Apidae richness, latitude and resource availability (measured as number of food plant species). Upper graph: the number of social Apidae species does not change with latitude. Middle graph: social Apidae comprise a lower percentage of all bees from the equator towards the South. Lower graph: species packing (the number of social bee species divided by the number of food plants) decreases with total number of food plants in the studies. For details on statistics see text. 


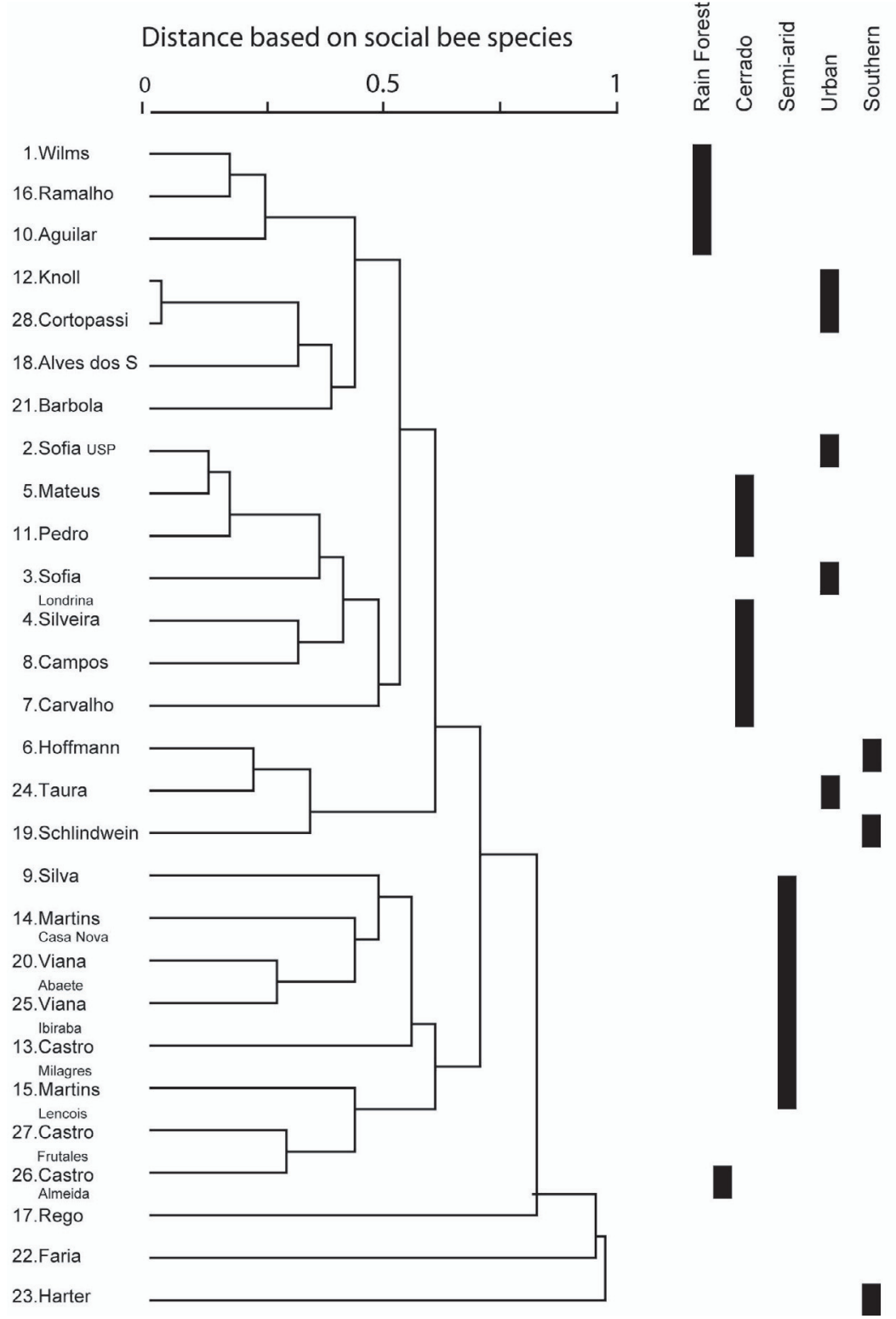

Figure 4. Result of the clustering of study sites based on the social Apidae species recorded for each site. For clustering method see text. Note that the main natural habitats tend to harbour similar social bee species. This finding is, however, confounded by the non-random layout of sites over Brazil (Fig. 1).

that the predicted trend in species packing may not hold for assemblages of generalist bees. An explanation might be that a wider range of food plants creates new niches for specialists, but does not necessarily create more niches for generalists, e.g. social bees.
Whereas richness is not directly influenced by habitat, the various studies within a natural habitat type were very similar to each other in social Apidae fauna (Fig. 4). A clusteranalysis of all study sites based on the identity of their social Apidae shows that the rain 


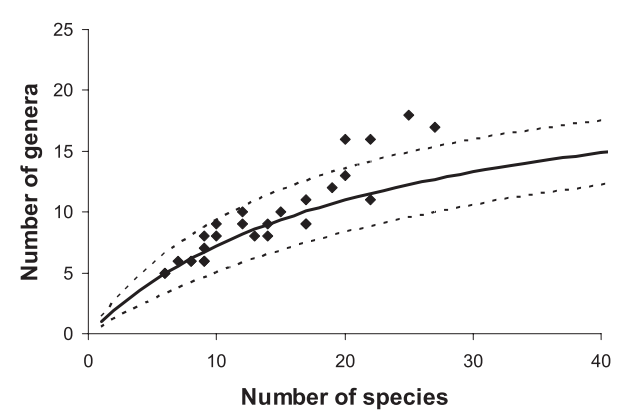

Figure 5. The number of genera found in the studies tends to be overrepresented. The curve is based on rarefaction analysis and depicts the number of genera to be expected in samples from low to high species diversity if species would be drawn randomly from the pooled datasets. The dotted lines are the $90 \%$ high and low confidence intervals (for details on methods see text). Each study is represented by a single dot. Four studies contained significantly more different genera than expected.

forest sites, cerrado sites, and the semi-arid sites form separate groups. Unfortunately, the habitats are highly clustered in space as well and the result of the cluster-analysis is probably due to a combination of biogeographical and habitat-related factors.

In most large genera only one or two species are commonly found across habitats and latitudes. They combine for $45-65 \%$ of all occurrences of their genus. Most other species are represented in only few studies. The 15 commonest species were Trigona spinipes (26 studies), Apis mellifera (22), Bombus morio (20), Tetragonisca angustula (16), Bombus atratus (15), Nannotrigona testaceicornis (11), Melipona quadrifasciata (11), Scaptotrigona bipunctata (10), Plebeia droryana (9), Partamona helleri (9), Schwarziana quadripunctata (9), Paratrigona subnuda (8), Trigona hyalinata (8), Friesella schrottkyi (7), Plebeia emerina (7). Note that there are nine different genera in the top 10 and 12 genera in the top 15 . Does this mean that bees in local bee assemblages tend to be from different genera? To address this question we calculated the number of different genera that would have been found at random by means of rarefaction analysis (Fig. 5). Four studies reported significantly more genera than expected and no studies reported fewer genera than expected. In total, 15 studies are found above the line of expectation and only 6 below the line (binomial test: $P=0.04$ ). This seems to indicate that the number of bee genera is overrepresented in at least some localities. The reason may be that con-generic species are more similar in foraging niche (and possibly nesting niche) and suffer more competition from each other than from less related species (see also Martins et al., 2003). The observed pattern is consistent with the concept of limiting similarity (see discussion).

\section{HAVE ALL SOCIAL APIDAE EQUALLY BROAD DIETS?}

When measuring resource use by organisms we measure the organism's realized niche. This realized niche is a result of ecological interactions with the organism's fundamental niche (Hutchinson, 1957; Keddy, 2001). The fundamental niche is what a species would occupy in absence of competitors and it is limited by the morphological and physical capabilities of the species. Niche differentiation, i.e. species-specific specialization, and dominance interactions between species are the two mechanisms that lead to a species' realized niche. These two mechanisms are very difficult to infer from observations on the realized niche. Single-species experiments can show aspects of the fundamental niche. Stingless bee species, for example, vary in their preference for sugar concentration when drinking freely from feeders (Roubik et al., 1995) and differences in body colour affect the thermal properties of stingless bees (Pereboom and Biesmeijer, 2003), which in turn leads to differences in flower choice and in sugar concentration of the collected nectar (Biesmeijer et al., 1999a, b).

Nineteen of the studies we selected provided bee abundance data that allowed us to calculate niche breadth. The standardized Shannon-Wiener function was calculated for all social bee species with at least 10 plant visits in a given study. Most species occurred in one or only a few studies, except for Trigona spinipes and Apis mellifera (both 
Table III. Average niche breadth (Shannon Index) of genera of social bees. The different letters in the last column indicate statistical differences (ANOVA, F = 7.7, $P<0.0005$; followed by Tukey HSD for multiple comparisons).

\begin{tabular}{lccccccc}
\hline Bee genus & N & Number of species & Number of studies & average & \pm & SD & \\
\hline Scaptotrigona & 14 & 7 & 9 & 0.26 & \pm & 0.14 & $\mathrm{a}$ \\
Partamona & 7 & $1-2$ & 7 & 0.37 & \pm & 0.15 & $\mathrm{a} / \mathrm{b}$ \\
Frieseomelitta & 7 & 4 & 6 & 0.40 & \pm & 0.20 & $\mathrm{a} / \mathrm{b} / \mathrm{c}$ \\
Nannotrigona & 6 & 2 & 6 & 0.43 & \pm & 0.18 & $\mathrm{a} / \mathrm{b} / \mathrm{c}$ \\
Trigona & 15 & 5 & 9 & 0.43 & \pm & 0.19 & $\mathrm{~b} / \mathrm{c}$ \\
Bombus & 21 & 4 & 12 & 0.44 & \pm & 0.13 & $\mathrm{~b}$ \\
Melipona & 18 & 8 & 9 & 0.44 & \pm & 0.14 & $\mathrm{~b} / \mathrm{c}$ \\
Tetragonisca & 7 & 1 & 7 & 0.50 & \pm & 0.14 & $\mathrm{~b} / \mathrm{c} / \mathrm{d}$ \\
Plebeia & 19 & $4-5$ & 10 & 0.51 & \pm & 0.11 & $\mathrm{~b} / \mathrm{c} / \mathrm{d}$ \\
Tetragona & 6 & 3 & 5 & 0.53 & \pm & 0.08 & $\mathrm{~b} / \mathrm{c} / \mathrm{d}$ \\
Paratrigona & 5 & 2 & 5 & 0.56 & \pm & 0.08 & $\mathrm{~b} / \mathrm{c} / \mathrm{d}$ \\
Trigona spinipes & 17 & 1 & 17 & 0.59 & \pm & 0.12 & $\mathrm{c} / \mathrm{d}$ \\
Apis mellifera & 17 & 1 & 17 & 0.66 & \pm & 0.11 & $\mathrm{~d}$ \\
\hline
\end{tabular}

occurred in 17 studies). To be able to compare niche breadth among various groups of bees, we grouped the remaining species per genus (Tab. III). Niche breadth differed significantly between two groups of social Apidae (those indicated with index a and $\mathrm{d}$ in the rightmost column in Tab. III). Niche breadth was lowest for Scaptotrigona, and highest for the two most common species, Trigona spinipes and Apis mellifera.

\subsection{Niche breadth reflecting the fundamental foraging niche}

Differences in niche breadth might reflect differences in fundamental foraging niche. However, we found that collective foraging mode, colony size, and bee size did not explain differences in niche breadth (KruskallWallis test: $P>0.2$ for all three comparisons). In relation to foraging mode, the taxa foraging in large groups were not homogeneous in niche breadth, whereas the other two categories were homogeneous (Levene statistic $=$ 4.67, $P=0.04$; Fig. 6). Among the group foragers, Scaptotrigona and Partamona have the lowest niche breadth of all social Apidae, whereas Trigona spinipes and Apis mellifera have the broadest niches of all social Apidae (Tab. III).

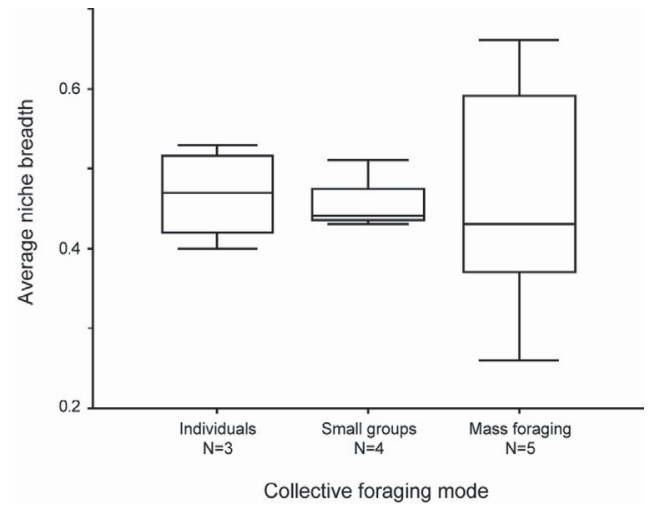

Figure 6. Box plot showing that the average niche breadth is similar for species groups with different collective foraging units. The variance is not homogeneous among the mass foraging species, which is related to differences in foraging strategies (see text).

The low niche breadth of Scaptotrigona and Partamona is not a result of narrow floral specialization. They used a wide array of food plants from more than 100 different genera and niche breadth increased linearly with the number of food plants (Pearson correlation; both genera: $\mathrm{R}^{2}=0.998, P<0.001$, Scaptotrigona 6 species, Partamona 5 species). Their food sources seem to include a high proportion of species with dense clusters of small white 
or cream-colored flowers. In-depth analysis of traits of bee food plants is beyond the scope of this paper, but may provide further insight in niche breadth differences (e.g. Wilms and Wiechers, 1997). Ramalho (1990) also mentions that Scaptotrigona has among the narrowest diets in the suburban campus of the University of São Paulo. Although, the bees were installed next to the botanical garden and a secondary forest rich in floral resources, three Scaptotrigona species used fewer plant species intensively for pollen collection than species of 5 other stingless bee genera in the same location. Below we will argue that the heterogeneity in niche breadth among the group foragers is related to differences in foraging strategies (non-aggressive group foraging versus aggressive group foraging).

\subsection{Niche breadth reflecting ecological interactions}

An influence of competition on realized niches may be found by comparing niche breadth across studies. Heithaus (1979a) observed that the average degree of specialization (the opposite of niche breadth) in a bee/wasp assemblage increases with the number of species. We found a similar relation with average niche breadth decreasing with increasing number of social Apidae (linear regression: $\mathrm{F}=8.96, P=0.009, \mathrm{n}=18$, $\mathrm{R}^{2}=0.32$ ). On the other hand, niche breadth was not related to resource availability (the number of food plant species) or the species packing (bees / food plant; linear regression: both $P>0.8$ ). Three of the 13 taxa (see Tab. III) display a similar negative relationship between social bee richness and niche breadth across the studies (Paratrigona, Tetragonisca and Trigona (not-including T. spinipes)), and for 10 of the 13 taxa the sign of the correlation is negative (binomial test: $P=0.04$ ). The three taxa mentioned above are very different in foraging tactics and it is not immediately clear why they should respond more to large assemblages than the other taxa. The overall trend of more specialization with more social bees suggests that all foraging strategies are sensitive to increased competitive pressure.

\section{HOW ARE EUSOCIAL BEE GENERA ASSOCIATED IN TERMS OF FOOD CHOICE?}

As mentioned before, the eusocial bees in tropical lowlands differ dramatically from most solitary bees in many traits. One of these traits is that they are active throughout the season and necessarily have relatively broad diets. The previous section showed that even within the eusocial bees there are significant differences in niche breadth. However, even the taxa with the lowest niche breadth use a wide range of food plants. This raises the question whether all taxa use all plant species and more importantly whether groups of species or genera can be distinguished that are similar in food plant use and differ from other groups. In some of the studies a cluster-analysis had been performed on the matrix of bee-plant interactions, but a comparison across studies has not been done before. We performed similar cluster-analyses on all datasets and used the results, i.e. degrees of association between pairs of taxa, as the basis for an across-studies cluster-analysis. The species identities vary greatly between the studies, therefore we first analyze whether con-generic species tend to be closely associated in the individual studies.

\subsection{Similarity in food plant use: intrageneric comparison}

Bees (like other organisms) will have most competition with co-existing members of their own species, and with other species in their genus, because congeneric bees tend to be similar, e.g. in size, colony structure, division of labour, and foraging strategies. In the Brazilian studies $28 \%$ of close associations (distance $<0.70$ ) in all cluster-analyses are by congeneric species pairs. This is significantly higher than the $8 \%$ expected from random clustering (Chi ${ }^{2}$-test: $\left.\chi=23.9, P<<0.001\right)$. In other words congeneric taxa use more similar food sources than less-related taxa. 


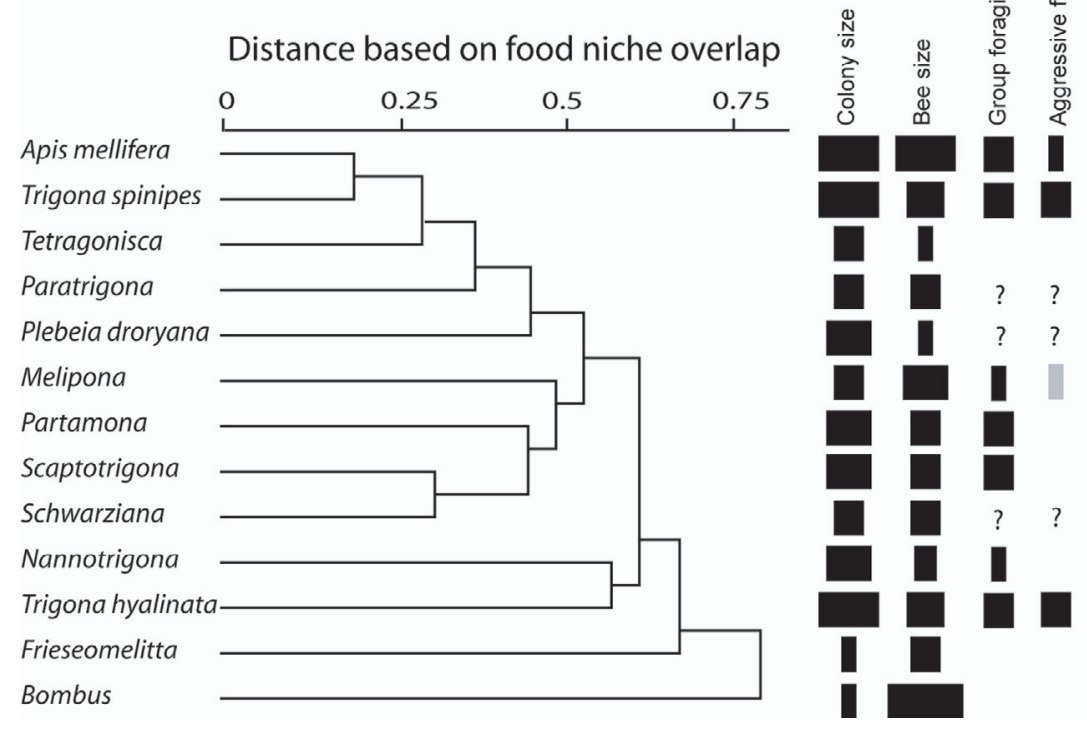

Figure 7. Results from a cluster-analysis of 13 common taxa based on the degree of association between taxa across all studies (for details on methods see text). Four bee characteristics are depicted in columns. The wider the column the more prominent the feature (large colony size and bee size, larger foraging groups, more aggressive foraging). The features that are insufficiently known are indicated by question marks. The gray bar in the last column indicates that some Melipona species have a moderate tendency for aggression, whereas others are more docile.

\subsection{Similarity in food plant use among social bee taxa}

To be able to compare associations between taxa across studies we were limited to using common taxa. Based on the specieslevel cluster-analysis we pooled species within genera, except for Trigona and Plebeia that seem to be more variable in congeneric association. For these genera we use the common species as units in our comparative analysis instead of data pooled from different species. In total 13 taxa were sufficiently common to be used in the comparative analysis: the species Apis mellifera, Plebeia droryana, Trigona spinipes, Trigona hyalinata; genera represented by a single species in our datasets Tetragonisca (angustula), Schwarziana (quadripunctata) and genera with pooled data from multiple species: Bombus, Frieseomelitta, Melipona, Partamona, Paratrigona, Scaptotrigona, and Nannotrigona.
For details on the comparative analysis see Methods section.

The new cluster-analyses per study were used to calculate the number of strong associations (distance $\leq 0.5$ ), weak associations (distance $\leq 0.7$ ) and all cases of co-occurrence across the studies. A matrix of the percentages of weak associations between taxa (of all possible co-occurrences) was then used for a higher-taxa across-studies cluster-analysis.

The cluster-analysis (Fig. 7) shows that two main groups exist and four very loosely associated taxa. The first group consists of five taxa, with Apis and T. spinipes having the strongest association (of all taxa). This is not surprising since they have very broad diets (Tab. III) and necessarily overlap considerably in the food plants they use. The other three taxa in that group are (probably) non-aggressive foraging with no or poor recruitment to food sources and thus largely individual foraging (Aguilar et al., 2005; experimental data for 
Paratrigona and Brazilian Plebeia are lacking). The second group includes two nonaggressive group foragers, Scaptotrigona and Partamona (e.g. Slaa, 2003), as well as Melipona and Schwarziana quadripunctata that may display similar foraging strategies.

Of the four remaining taxa, Bombus is most different from all other taxa in food plant use. Bumblebees are larger and stronger than all other eusocial Apidae and are (with Melipona) the only buzz-pollinators among the taxa. Since few authors recorded whether bees collected pollen or nectar from the flowers it remains unclear whether Bombus is an outlier based on a set of buzz-pollinated pollen sources or also on unique nectar sources. The other non-associated taxa are Frieseomelitta, Trigona hyalinata, and Nannotrigona. Little is known about these taxa, but they represent very different foraging strategies (Nieh et al., 2003; Slaa, 2003; Jarau et al., 2003).

Being associated strongly in relation to food sources does not necessarily mean that species compete. Spatial and temporal patterns vary continuously. However, if species share many of their food plants interactions are more likely than if they share few resources. Avoidance behaviour, on the other hand, may express itself as a weak association. If we analyze the prevalence of strong and weak associations across taxa it becomes clear that most taxa have a similar ratio of weak and strong interactions (Fig. 8a; Pearson correlation: $\rho=0.61, P=0.03, \mathrm{n}=13)$. The only taxon that deviates strongly from this correlation is Nannotrigona for which most associations with other taxa are strong. This seems surprising, because this bee is a rather small, non-aggressive forager with poor recruitment (Slaa, 2003). How can she cope with high overlap in food source use? Food source communication in Nannotrigona consists of general agitation behaviour and lacks information on food source location (Lindauer and Kerr, 1960). The result is that individuals quickly spread out over the surroundings to find any food source with the odour indicated by the scouts. In an experiment on recruitment and food source discovery (Slaa, 2003), Nannotrigona was indeed very fast to recruit and to find new food sources near the recruitment tar- get reported by scouts. By continuously moving to unexploited food sources, leaving a food source when the aggressive group foragers arrive and returning after they left, Nannotrigona is able to use similar food sources as many other bees, but at the same time have limited physical encounters at food sources (Johnson, 1983; Slaa, 2003). Nannotrigona will thus be found in low numbers on many flower patches, hence its niche breadth and high overlap with many other taxa. Its strongest association is with the aggressive group forager $T$. hyalinata (Fig. 7) which uses the strategy, that several Trigona use, of laying scent trails to lead large groups of recruits to highly profitable food sources that are then monopolized and fiercely defended against other bees (Nieh et al., 2003; Johnson and Hubbell, 1974; Slaa et al., 2003). This is time and work force intensive tactic and neither leads to fast recruitment, nor to quick discovery of new food sources (Slaa et al., 2003). Therefore it may provide opportunities for the Nannotrigona strategy to persist.

There is also a strong correlation between niche breadth and the percentage of strong associations (Fig. 8b; Pearson correlation: $\rho=0.65, P=0.02, \mathrm{n}=12$ ). This merely reflects the fact that if many plant species are visited, interactions with other species are more likely. More interesting are the taxa that deviate from this pattern: Bombus and Nannotrigona. Bombus has fewer strong associations and Nannotrigona has more strong associations than expected from the correlation. This confirms what we discussed before. Bombus uses different plant species than the other eusocial Apidae. Nannotrigona shares many plant species, but probably avoids physical interactions through its specific foraging strategy. The percentage of strong associations is not correlated with bee size, colony size or group foraging strategy (Pearson correlation: all $P>0.2$ ).

\section{DISCUSSION}

The aim of this meta-analysis was to elucidate some general patterns in social bee assemblages and their relations with food plants, and try to link these patterns with ecological and behavioural traits of the bees. The 

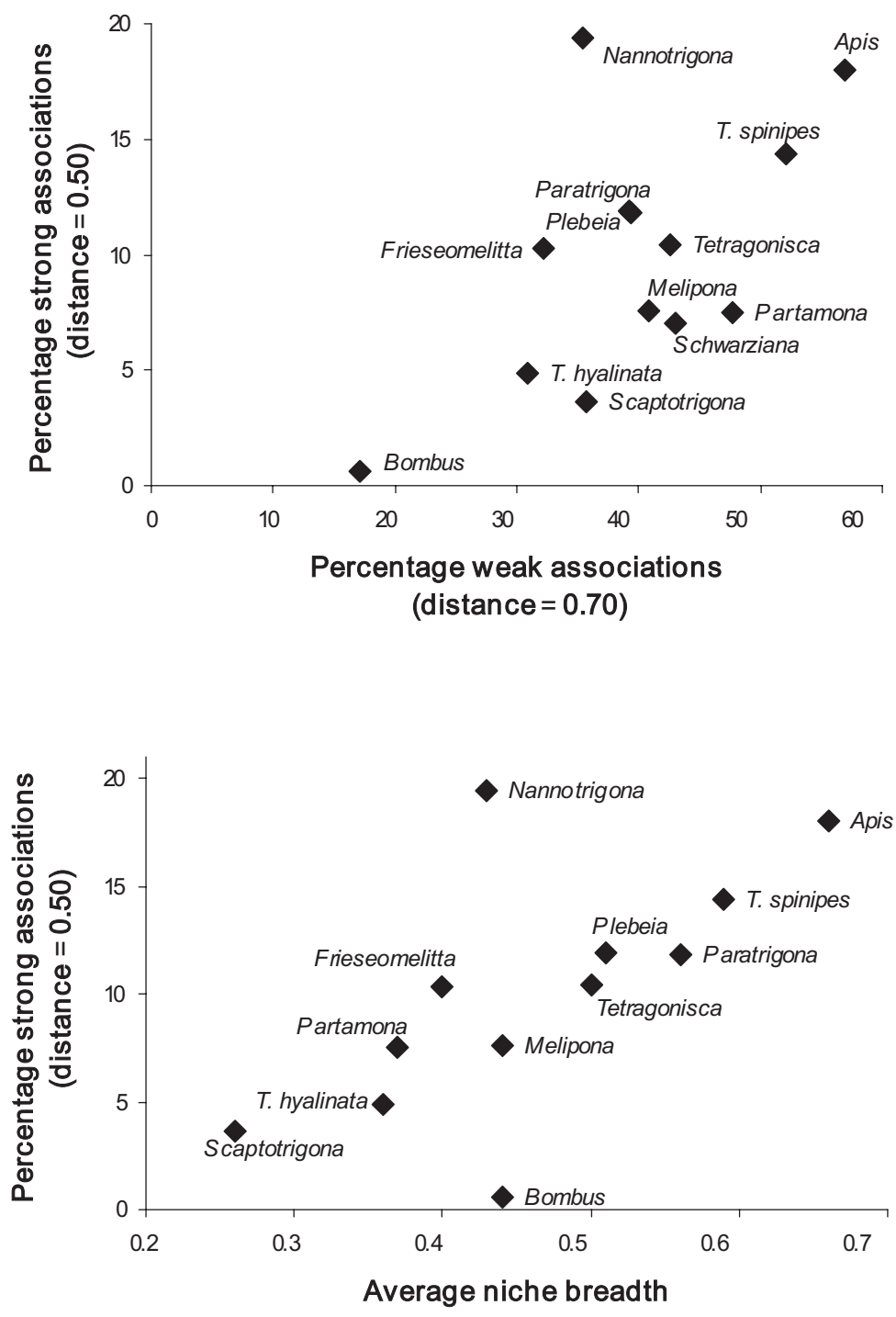

Figure 8. Upper graph: the ratio between close associations (high similarity in food sources) and weak associations (moderate similarity in food sources) can be seen as an indication for the importance of food source overlap (see text). In general, the more weak associations, the more strong associations. Interestingly, some taxa deviate from this rule. Possible reasons for this are discussed in the text. Lower graph: in general, social bees with broader food niches tend to overlap more with other social bee taxa (higher percentage of strong associations). Bombus and Nannotrigona deviate strongly from this pattern. For details on calculations and methods see text.

foraging patterns observed in the field represent the realized food niche and are the result of biotic and abiotic interactions working on top of the fundamental food niches of the participants. Information on complex tropical interaction networks is relatively scarce and tends to be limited to a single location (Roubik, 1979, all studies in Tab. I) or a few habitats (Heithaus, 1974, 1979). The studies we selected are unique in that they are very homogeneous in methodology and yet span a wide range of tropical and subtropical habitats. 
This allowed us to perform the first quantitative meta-analysis of the structure of social bee assemblages. Here we summarize and discuss the main findings.

Social Apidae are common throughout Brazil, but the size of assemblages varies considerably from less than 10 in semi-arid habitats to $20-30$ in savanna woodlands and Atlantic rain forest to 40 or more in the Amazon (Tab. I; Ducke in Roubik 1979, 1989). Local richness could not be explained by latitude or floral resources and was only weakly related to habitat (semi-arid harbouring less species).

Assemblages tend to consist largely of bees of different genera (Fig. 5). This is consistent with the idea of limiting similarity (MacArthur and Levins, 1967; Abrams, 1983) that states that co-existing species should be different in resource use. Where multiple species of a single genus co-exist, they tend to have a high similarity in food plant use. In these cases there might be either temporal or spatial separation of resources or scramble competition for rich food sources. Many non-aggressive individual and group foragers experience scramble competition when foraging and do not physically interact with other non-aggressive species (Slaa et al., 2003). Non-aggressive taxa (Bombus, Melipona, Scaptotrigona, Plebeia and Frieseomelitta) accounted for more than $90 \%$ (30 of 31 associations) of all cases of high overlap in floral resource use between congeneric taxa. The remaining association was between two aggressive Trigona species in a study where 6 of the 22 social bees were Trigona and the probability of a strong association between two of them was relatively high. The two most common aggressive group foragers, $T$. spinipes and $T$. hyalinata, have very different diets (Fig. 7) and probably do not interact regularly during foraging. This does not necessarily mean that scramble competition is a way to pack more species in the same niche and avoid the limiting similarity paradigm. Non-aggressive congeneric taxa can show very subtle niche partitioning that studies on flower visitation cannot reveal (e.g. Biesmeijer et al., 1999a, b).

Interestingly, the medium-sized scramble competitors are closely related in floral resource use (Fig. 7). The core of their food plants seems to consist of mass-flowering trees and shrubs with small white or creamy flowers (e.g. Ramalho et al., 1990). In the Atlantic rain forest, for example, $30 \%$ of the social bee food plants exhibit mass-flowering sometimes restricted to a single day each year (Wilms et al., 1996). A single mass-flowering tree is normally too big to be monopolized by a colony of aggressive Trigona bees and if several trees synchronize there flowering all scramblers quickly mobilize their work force to exploit the resource virtually undisturbed. They probably collect most of their pollen and nectar reserves (to survive dearth periods) in a couple bouts of superabundant resource availability.

Three other stingless bee taxa are also largely scramblers (although confirmation is needed for Paratrigona and Plebeia droryana; Fig. 7). They cluster together with the two supergeneralists, the honeybee and $T$. spinipes. All of them are small bees with no or poor recruitment and they forage individually or in small groups (Johnson, 1983; Aguilar et al., 2005; Slaa, 2003; Biesmeijer and Slaa, personal observation). We often observed interactions between these small bees and aggressive foragers at our sugar-water feeders (Slaa, 2003). They carefully pick a drinking place, quickly fill up and left the scene. The much larger Trigona did not seem to mind their presence although sometimes a small bee was attacked and instantly killed. The small bees tend to be most numerous after the aggressive foragers had left (Johnson, 1983; Slaa, 2003). They cleaned up the leftovers. This strategy has also been observed in semi-arid Caatinga and is referred to as persistent insinuation (Martins and Aguilar, 1992; see also Johnson, 1983). In this way small-sized scramblers can share the rich food sources with the dominant group foragers, something that medium-sized non-aggressive scramblers cannot easily do.

We need to mention here that the patterns of social bee food plant use recorded over the last decades in Brazil must not be interpreted lightly as species-specific patterns. The reason being that one of the largest natural experiments ever may have influenced foraging in native social bees in Brazil: the arrival and prolific spread of the African honeybees in the 
Neotropics. It is hard to imagine that the millions of honeybee colonies that currently coexist with the native social bees will not have reshaped the interactions. Indeed, honeybees tend to scare off some larger stingless bees from flower patches and may have negative effects on colony foraging (reviewed in Roubik, 1989). It may be that the impact is largest on the aggressive group foragers that are often not strong enough to eliminate Apis from food sources, which in turn may give other scramblers the opportunity to join in. On the other hand, Apis has large colonies and very efficient recruitment aimed at quick harvesting of the richest food sources. This potentially removes much of the food of the other medium-sized and large scramblers, e.g. Partamona, Scaptotrigona, Melipona. From our analysis we cannot determine whether the narrower niches of Partamona and Scaptotrigona are a result of their foraging strategies, of the interactions with Apis, or both. European honeybees seem to have responded to the arrival of the African bees in Yucatan by shifting flower choice and increasing resource specialization (Villanueva and Roubik, 2004) which suggests something similar might have happened to stingless bees.

The advantage of the large set of studies that we used is the consistency in their sampling methods. This allowed us to perform a comparative quantitative analysis across habitats over a long latitudinal range. The structure of the social bee assemblages in these studies showed a certain degree of similarity and the broad associations between the different social bee groups (introduced honeybees, stingless bees and bumblebees) are clearly correlated with specific traits of their foraging ecology. The generality of our findings could be analyzed using palynological studies (e.g. Ramalho et al., 1990) and studies of nesting assemblages (see Roubik, 2006; Slaa, 2006). The broad ecological inventories that we used in our meta-analysis do neither reveal the influence of flower characteristics on food choice, nor do they elucidate the intricate details of spatial and temporal niche differentiation. A thorough understanding of social bee - food plant interactions can only be obtained by investigating all different lev- els: resource characteristics, pollinator foraging preferences, and pollinator interactions.

\section{ACKNOWLEDGEMENTS}

This study was made possible by financial support provided by FAPESP for which we are very grateful. We like to thank Vera Imperatriz-Fonseca, Astrid Kleinert, Isabel Alves dos Santos, Blande Viana, Cris Gianini, and Marina Castro for assistance during the data analysis and fruitful discussions and Klaus Hartfelder and two anonymous referees for comments on the manuscript. The members of the bee laboratory of USP, São Paulo, made our stay highly enjoyable and very rewarding.

Résumé - Structure des ensembles d'abeilles eusociales au Brésil. Les relations abeilles socialesplantes alimentaires ont été abondamment étudiées, en particulier dans les néotropiques. Il s'agit pourtant de la première comparaison quantitative et d'une synthèse d'un large ensemble d'études (28) remarquablement similaires s'intéressant aux plantes alimentaires des abeilles eusociales au Brésil (Tab. I, Fig. 1). Un autre ensemble d'étude n'a pas pu être inclus pour diverses raisons (Tab. II). Les sites d'étude comprennent la forêt tropicale, la savane arborée (cerrado), les régions boisées semiarides (caatinga), les dunes et les habitats modifiés. Le schéma de la richesse en abeilles sociales, de la taille de la niche et des associations entre taxons d'abeilles sociale peut s'expliquer en partie par les différences propres aux espèces concernant le comportement, les caractéristiques de butinage et la réponse à la compétition interspécifique. Les ensembles d'abeilles sont constitués d'un nombre semblable d'Apidae sociaux mais en pourcentages plus élevés lorsqu'on se rapproche de l'équateur (Figs. 2, 3). Les habitats semi-arides hébergent légèrement moins d'Apidae sociaux que les autres habitats et les forêts amazoniennes sont probablement les plus riches. La taille de la niche varie de façon significative entre abeilles eusociales; les butineuses en groupe de taille moyenne et non agressives, par ex. Scaptotrigona, Partamona, ont la niche la plus étroite, les super-généralistes, tels que Trigona spinipes, Apis mellifera, ont le régime le plus vaste (Tab. III). La taille de la niche décroît généralement avec le nombre d'espèces d'abeilles sociales que compte l'ensemble, indiquant que la compétition interspécifique influence le choix du régime. L'analyse de groupement des taxons communs montre la présence de deux groupes principaux en termes d'utilisation des plantes alimentaires (Fig. 7) : les butineuses en groupe de taille moyenne et non agressives (Scaptotrigona, Partamona, Schwarziana, Melipona) et un autre groupe comprenant 
les butineuses en groupe agressives de Trigona spinipes, l'Abeille domestique et trois petits bousculeurs (Plebeia droryana, Tetragonisca, Paratrigona). Bombus, Trigona hyalinata, Nannotrigona et Frieseomelitta ne sont associés à aucun autre taxon.

\section{Apidae / abeille sans aiguillon / Meliponini / com- pétition / partage des niches}

Zusammenfassung - Die Struktur eusozialer Bienenansammlungen in Brasilien. Die Beziehungen zwischen sozialen Bienen und Nahrungspflanzen sind gut untersucht, besonders auch in den Neotropen. Dies ist die erste zusammenfassende quantitative Untersuchung eines großen Bestands an bemerkenswert einheitlichen Studien, die sich mit eusozialen Bienen und ihren Futterpflanzen in Brasilien befassen (Tab. I, Abb. 1). Ein weiterer Bestand an Untersuchungen konnte aus den verschiedensten in Tabelle II gelisteten Gründen nicht einbezogen werden. Die Untersuchungsgebiete schlossen Regenwald, Savanne, Waldgebiete (Cerrado), Habtrockenwälder (Caatinga), Dünen und veränderte Habitate ein. Die Verteilungsmuster des Reichtums an sozialen Bienen, der Nischenbreiten und der Assoziationen zwischen den Taxa sozialer Bienen konnte zum Teil aus artspezifischen Verhaltensunterschieden, Sammeleigenschaften und der Reaktion auf zwischenartlichen Wettbewerb erklärt werden. Bienenansammlungen enthalten in Richtung auf den Äquator ähnliche Bienenanzahlen, aber höhere Anteile an sozialen Bienen (Abb. 2, 3). In halbtrockenen Habitaten waren soziale Bienen geringfügig seltener vertreten, in den Amazonaswäldern waren sie vermutlich am häufigsten. Die Nischenbreite variierte signifikant zwischen eusozialen Bienen mit mittelgroßen nicht-aggressiven Gruppensammlern, wobei zum Beispiel Scaptotrigona und Partamo$n a$ das engste und Supergeneralisten wie Trigona spinipes und Apis mellifera das am stärksten gefächerte Nahrungsspektrum hatten (Tab. III). Die Nischenbreiten nahmen generell mit der Anzahl sozialer Bienenarten in den Ansammlungen $\mathrm{ab}$, dies weist darauf hin, dass das Nahrungsspektrum durch zwischenartliche Konkurrenz beeinflusst wird. Klusteranalysen der verbreitetsten Arten zeigten im Bezug auf das Futterpflanzenspektrum zwei Hauptgruppen auf (Abb. 7): mittelgroße nichtagressive Gruppensammler (Scaptotrigona, Partamona, Schwarziana, Melipona) und eine Gruppe mit den agressiven Gruppensammlern Trigona spinipes, Honigbienen und drei kleinen Drängler (Plebeia droryana, Tetragonisca, Paratrigona). Bombus, Trigona hyalinata, Nannotrigona und Frieseomelitta waren mit keiner der anderen Taxa assoziiert.

Vergesellschaftungsökologie / Stachellose Bienen / Wettbewerb / Nischenaufteilung / Meliponinen / Apidae

\section{REFERENCES}

Abrams P. (1983) The theory of limiting similarity, Annu. Rev. Ecol. System. 14, 359-376.

Aguiar A.J.C. (2001) Comunidade de abelhas (Hymenoptera, Apoidea Apiformes) da vegetação de Tabuleiro da Reserva Biológica Guaribas (Mamanguape, Paraiba), Msc thesis Ciências Biológicas, Universidade Federal da Paraiba, Brazil.

Aguilar J.B.V. (1998) A comunidade de abelhas (Hymenoptera: Apoidae) da reserva florestal de morro grande, Cotia, São Paulo, $\mathrm{PhD}$ thesis Instituto de Biociências da Universidade de São Paulo, Brazil.

Aguilar I., Fonseca A., Biesmeijer J.C. (2005) Recruitment and communication of food source location in three species of stingless bees (Hymenoptera, Apidae, Meliponini), Apidologie $36,313-324$.

Albuquerque P.M.C. (1998) Abelhas silvestres (Hymenoptera, Apoidea) e suas fonts de alimento em um ecossistema de dunas, na ilha do Maranhão, MA, Brasil: composição, fenelogia e interações, $\mathrm{PhD}$ thesis USP Riberão Preto, SP, Brazil, 208 p.

Alves dos Santos I. (1996) Bienen und melittophile Blütenpflanzen in der Küstenregion und im Atlantischen Regenwald von Rio Grande do Sul (Brasilien), mit einer Fallstudie $\mathrm{zu}$ Langzungenbienen und tristylen Wasserhyazinthen, $\mathrm{PhD}$ thesis, Fakultät für Biologie der Eberhard-Karls-Universität Tübingen, Germany.

Antonini Y. (2002) Efeitos de variáveis ecológicas na ocorrência de Melipona quadrifasciata (Apidae: Meliponini) em fragmentos urbanos e rurais, $\mathrm{PhD}$ thesis Ecologia Conservação Manejo de Vida Silvestre, da Universidade Federal de Minas Gerais.

Barbola I.F. (1993) A comunidade de Apoidea (Hymenoptera) da reserva Passa Dois (Lapa, Paraná): Diversidade, fenelogia e relações tróficas, Msc thesis, Ciências Biológicas, da Universidade Federal do Paraná, Brazil.

Barth F.G. (1991) Insects and Flowers - The biology of a partnership, Princeton University Press, Princeton, NJ.

Biesmeijer J.C., Slaa E.J. (2004) Information flow and organization of stingless bee foraging, Apidologie 35, 143-157.

Biesmeijer J.C., Smeets M., Richter J.A.P., Sommeijer M.J. (1999a) Nectar foraging by stingless bees in Costa Rica: botanical and climatological influences on sugar concentration of nectar collected by Melipona, Apidologie 30, 43-55.

Biesmeijer J.C., Richter J.A.P., Smeets M., Sommeijer M.J. (1999b) Niche differentiation in nectarcollecting stingless bees: the influence of 
morphology, floral choice and interference competition, Ecol. Entomol. 24, 380-388.

Biesmeijer J.C., Slaa E.J., Castro M.S. de, Viana B.F., Kleinert A. de M.P., Imperatriz-Fonseca V.L. (2005) Connectance of Brazilian Social bee-food plant networks is influenced by habitat, but not by latitude, altitude or network size, Biota Neotrop. $5,1-10$

Campos M.J.O. (1989) Estudo das interacões entre a comunidade de Apoidae, na procura de recursos alimentares, e a vegetacão de cerrado da reserva de Corumbatai, S.P. PhD thesis Departamento de ciências biológicas da Universidade Federal de Sao Carlos, S.P., Brazil.

Carvalho A.M.C. (1990) Estudo das inetracões entre a apifauna e a flora apícola em vegetacão de cerrado - Reserva Ecológica do Panga - Uberlândia MG. MSc thesis Faculdade de Filosofia, Ciências e Letras de Riberão Preto, Universidade de São Paulo, S.P., Brazil.

Casgrain P., Legendre P. (2001) The R Package for Multivariate and Spatial Analysis, version 4.0 d5 - User's Manual, Département de sciences biologiques, Université de Montréal, Available on http://www.bio.umontreal.ca/casgrain/fr/labo/R/ index.html (accessed on 20 January 2006).

Castro M.S. de (1994) Composição, fenelogia e visita às flores pelas espécies de Apidae em um ecossistema de caatinga (Nova Casa Nova - Bahia 9²6'S / 41 ${ }^{\circ} 50$ 'W), MSc thesis Instituto de Biociências da Universidade de São Paulo, Brazil.

Castro M.S. de (2001) A comunidade de abelhas (Hymenoptera; Apoidae) de uma area de caatinga arbórea entre os inselbergs de Milagres (12 ${ }^{\circ} 53^{\prime} \mathrm{S}$; 39 $\left.51^{\circ} \mathrm{W}\right)$, Bahia, $\mathrm{PhD}$ thesis Instituto de Biociências da Universidade de São Paulo, Brazil.

Colwell R.K. (1997) EstimateS: Statistical estimation of species richness and shared species from samples. Version 5. User's Guide and application published at: http://viceroy.eeb.uconn.edu/estimates (accessed on 20 January 2006).

Cortopassi-Laurino M. (1982) Divisão de recursos tróficos entre abelhas cociais principalmente em Apis mellifera Linné e Trigona (Trigona) spinipes Fabricius (Apinae, Hymenoptera), PhD thesis Instituto de Biociências da Universidade de São Paulo, Brazil.

Faria G.M. (1994) A flora e a fauna apícola de um ecossistema de campo rupestre, Serra do Cipó - MG, Brasil: Composição, fenologia e suas interações, $\mathrm{PhD}$ thesis Instituto de Biociências, Universidade de São Paulo, Brazil.

Gates S. (2002) Review of methodology of quantitative reviews using meta-analysis in ecology, J. Anim. Ecol. 71, 547-557.

Hakim J.R.C. (1983) Estudo ecológico da comunidade de abelhas silvestres (Hymenoptera, Apoidea) do Parque da cidade, comparado ao de outras areas de
Curitiba, Paraná, MSc thesis, Ciências Biológicas, Universidade Federal do Paraná, Brazil.

Harder L.D. (1985) Morphology as a predictor of flowerchoice by bumble bees, Ecology 66, 198-210.

Harter B. (1999) Bienen und ihre Trachtpflanzen im Araukarien-Hochland von Rio Grande do Sul, mit Fallstudien zur Bestäubung von Pionierpflanzen, $\mathrm{PhD}$ thesis, Fakultät für Biologie der EberhardKarls-Universität Tübingen.

Heithaus E.R. (1974) Role of plant-pollinator interactions in determining community structure, Ann. Missouri Bot. Garden 61, 675-691.

Heithaus E.R. (1979a) Flower-feeding specialization in wild bee and wasp communities in seasonal neotropical habitats, Oecologia 42, 179-194.

Heithaus E.R. (1979b) Community structure of neotropical flower visiting bees and wasps: diversity and phenology, Ecology 60, 190-202.

Hoffmann M. (1990) Estrutura e importância de uma comunidade de abelhas (Hymenoptera: Apoidae) no Rio Grande do Sul, para a polinização de plantas cultivadas, $\mathrm{PhD}$ thesis Ciências Biológicas, Universidade Federal do Parana, Brazil.

Hutchinson G.E. (1957) Concluding remarks, Cold Spring Harbor Symp, Quant. Biol. 22, 415-427.

Jarau S., Hrncir M., Schmidt V.M. (2003) Effectiveness of recruitment behavior in stingless bees (Apidae, Meliponini), Insectes Soc. 50, 365-374.

Johnson L.K. (1983) Foraging strategies and the structure of stingless bee communities in Costa Rica, in: Jaisson P. (Ed.), Social Insects in the Tropics 2, Université Paris-Nord, Paris, pp. 31-58.

Johnson L.K., Hubbell S.P. (1974) Aggression and competition among stingless bees - field studies, Ecology 55, 120-127.

Kaminski A.C. (2001) Abelhas visitants de três espécies de Clusia (Clusiaceae) para coleta de resinas florais, com ênfase en Ptilotrigona lurida (Smith 1854) (Hymenoptera, Apidae, Meliponinae), em uma floresta de terra firme na Amazônia Central, $\mathrm{MSc}$ thesis Biologia Tropical e Recursos Naturais do convênio INPA/UA.

Keddy P.A. (2001) Competition, 2nd ed., Kluwer, Dordrecht.

Kevan P.G., Imperatriz-Fonseca V.L. (2002) Pollinating bees - The conservation link between agriculture and nature, Ministry of Environment, Brasilia DF, Brazil available at: http://www.webbee.org.br/bpi/livro_polinizadores. htm (accessed on 20 January 2006).

Kleinert-Giovannini A., Imperatriz-Fonseca V.L. (1987) Aspects of the Trophic Niche of MeliponaMarginata-Marginata Lepeletier (Apidae, Meliponinae), Apidologie 18, 69-100.

Knoll F.R.N. (1985) Abundância relativa das abelhas no campus da Universidade de São Paulo $\left(23^{\circ} 33^{\prime} \mathrm{D}\right.$; $\left.46^{\circ} 43^{\prime} \mathrm{W}\right)$, com especial referência 
a Tetragonisca angustula Latreille, MSc thesis Instituto de Biociências da Universidade de São Paulo, Brazil.

Knoll F.R.N. (1990) Abundância relativa, sazonalidade e preferencias florais de Apidae em uma area urbana (233' D; 464' $\mathrm{W}), \mathrm{PhD}$ thesis Instituto de Biociências, Universidade de São Paulo, Brazil.

Krebs C.J. (1999) Ecological Methodology, 2nd ed., Addison-Welsey Educational Publishers, Inc. Menlo Park, CA, USA.

Laroca S. (1974) Estudo feno-ecológico em Apoidea do litoral e primeiro planalto Paranaenses, MSc thesis, Instituto de Biologia, da Universidade Federal do Paraná, Brazil.

Legendre P., Legendre L. (1998) Numerical Ecology, 2nd English ed., Developments in Environmental Modelling 20, Elsevier, Amsterdam, The Netherlands.

Lindauer M., Kerr W.E. (1960) Communication between the workers of stingless bees, Bee World 41, $65-71$.

MacArthur R.H., Levins R. (1967) The limiting similarity, convergence, and divergence of coexisting species, Am. Nat. 101, 377-385.

Machado C.P. (2002) Diversidade e conservação de Apoidae, $\mathrm{PhD}$ thesis Instituto de Biociências da Universidade de São Paulo, Brazil.

Martins C.F. (1990) Estrutura da comunidade de abelhas (Hymn., Apoidea) na caatinga (Casa nova, BA) e na Chapada Diamantina (Lençóis, $\mathrm{BA}), \mathrm{PhD}$ thesis Instituto de Biociências da Universidade de São Paulo, Brazil.

Martins C.F., Aguilar J.B.V. (1992) Visits at a feeding station during the dry season of Africanized honey bees and native social insects in the Brazilian Caatinga (Hymenoptera: Apidae), Entomol. Gen. 17, 9-15.

Martins C.F., Moura A.C.A., Barbosa M.R.V. (2003) Bee plants and relative abundance of corbiculate Apidae species in a Brazilian Caatinga area, Rev. Nordestina Biol. 17, 63-74.

Mateus S. (1998) Abundancia relativa, fenelogia e visita às flores pelos Apoidae do cerrado da estação ecológica de Jataí, Luiz Antônio - SP, MSc thesis Faculdade de Filosofia, Ciências e Letras de Riberão Preto, Universidade de São Paulo, S.P., Brazil.

Moldenke A.R. (1975) Niche specialization and species diversity along a California transect, Oecologia 21, 219-242.

Morse D.H. (1982) Foraging relationships within a guild of bumblebees, Insectes Soc. 29, 445-454.

Nagamitsu T., Inoue T. (1997) Aggressive foraging of social bees as a mechanism of floral resource partitioning in an Asian tropical rain forest, Oecologia 110, 432-439.
Nagamitsu T., Momose K., Inoue T., Roubik D.W. (1999) Preference in flower visits end partitioning in pollen diets of stingless bees in an Asian tropical rain forest, Res. Pop. Ecol. 41, 195-202.

Nagamitsu T., Inoue T. (2002) Foraging activity and pollen diets of subterranean stingless bee colonies in response to general flowering in Sarawak, Malaysia, Apidologie 33, 303-314.

Nagamitsu T., Inoue T. (2005) Floral resource utilization by stingless bees (Apidae, Meliponini), in: Roubik D.W., Sakai S., Karim A.A.H. (Eds.), Pollination ecology and the rain forest, Springer, pp. 73-88.

Nieh J.C. (2004) Recruitment communication in stingless bees (Hymenoptera, Apidae, Meliponini), Apidologie 35, 159-182.

Nieh J.C., Contrera F.A.L., Nogueira-Neto P. (2003) Pulsed mass recruitment by a stingless bee, Trigona hyalinata, Proc. R. Soc. B 270, 21912196.

Orth A.I. (1983) Estudo ecológico de abelhas silvestres (Hymenoptera, Apoidea) em Caçador, SC, com enfase em polinizadores potenciais da Macieira Pyrus malus (L.) (Rosaceae), MSc thesis, Ciências Biológicas da Universidade Federal do Paraná, Brazil.

Pedro S.R.M. de (1992) Sobre as abelhas (Hymenoptera, Apoidea) em um ecossistema de cerrado (Cujuru, NE do estado de São Paulo): composição, fenelogia e visita às flores, MSc thesis Faculdade de Filosofia, Ciências e Letras de Riberão Preto, Universidade de São Paulo, S.P., Brazil.

Pereboom J.J.M., Biesmeijer J.C. (2003) Thermal constraints for stingless bee foragers: the importance of body size and coloration, Oecologia 137, 4250 .

Ramalho M. (1990) Foraging by stingless bees of the genus, Scaptotrigona (Apidae, Meliponinae), J. Apic. Res. 29, 61-67.

Ramalho M. (1995) Diversidade de abelhas (Apoidae, Hymenoptera) em um remanescente de floresta atlântica em São Paulo, PhD thesis Instituto de Biociências da Universidade de São Paulo, Brazil.

Ramalho M., Kleinert-Giovannini A., ImperatrizFonseca V.L. (1990) Important bee plants for stingless bees (Melipona and Trigonini) and africanized honeybees (Apis mellifera) in neotropical habitats - a review, Apidologie 21, 469-488.

Rêgo M.M.C. (1998) Abelhas silvestres (Hymn. Apoidea) em um ecosistema de cerrado s.1. (Chapadinha - MA, Brasil): uma abordagem biocenótica, PhD thesis Faculdade de Filosofia, Ciências e Letras de Riberão Preto, Universidade de São Paulo, S.P., Brazil.

Roubik D.W. (1979) Africanized honeybees, stingless bees, and the structure of tropical plant-pollinator communities, in: Caron D. (Ed.), Proc. IV Int. 
Symp. Poll. Maryland Agric. Exp. Sta. Misc. Publ. 1, pp. 403-417.

Roubik D.W. (1989) Ecology and natural history of tropical bees, Cambridge Univ. Press, Cambridge.

Roubik D.W. (1990) Niche pre-emption in tropical bee communities: A comparison of neotropical and malesian faunas, in: Sakagami S.F., Ohgushi R., Roubik D.W. (Eds.), Natural history of social wasps and bees in equatorial Sumatra, Hokkaido Univ. Press, Sapporo, Japan, pp. 245-257.

Roubik D.W. (1992) Loose niches in tropical communities: Why are there so few bees and so many trees? in: Hunter M.D., Ohgushi H., Price P.W. (Eds.), Effects of resource distribution on animalplant interactions, Academic Press, pp. 327-354.

Roubik D.W. (1993) Direct costs of forest reproduction, bee-cycling and the efficiency of pollination modes, J. Biosci. 18, 537-552.

Roubik D.W. (2006) Stingless bee nesting biology, Apidologie 37, 124-143.

Roubik D.W., Yanega D., Aluja S.M., Buchmann S.L., Inouye D.W. (1995) On optimal nectar foraging by some tropical bees (Hymenoptera: Apidae), Apidologie 26, 197-211.

Sakagami S.F., Laroca S., Moure J.S. (1967) Wild bee biocenotics in São José dos Pinhais (PR), south Brasil, Preliminary report, J. Fac. Sci. Hokkaido Univ., Ser. VI, Zool. 16, 253-291.

Schlindwein C. (1995) Wildbienen und ihre Trachtpflanzen in einer südbrasilianischen Buschlandschaft: Fallstudie Guaritas, Bestäubung bei Kakteen und Loasaceen, PhD thesis, Fakultät für Biologie der Eberhard-Karls-Universität Tübingen, Germany.

Schwartz Filho D. (1993) A comunidade de abelhas silvestres (Hymenoptera, Apoidea) da ilha das cobras (Parana, Brasil): aspectos ecológicos e biogeográficos, MSc thesis, Ciências Biológicas, da Universidade Federal do Paraná, Brazil.

Silva M.C.M. (1998) Estrutura da comunidade de abelhas (Hymenoptera, Apoidae) de uma area de restinga (praia de intermares, Cabedelo Paraíba, Nordeste do Brasil), MSc thesis Ciências Biológicas, Universidade Federal da Paraiba, Brazil.

Silveira F.A. da (1989) Abelhas silvestres (Hymenoptera: Apoidea) e suas fonts de alimento no cerrado da estação florestal de experimentação de Paraopeba - Minas Gerais, MSc thesis da Universidade Federal de Vicosa, MG, Brazil.

Slaa E.J. (2003) Foraging ecology of stingless bees: from individual behaviour to community ecology, $\mathrm{PhD}$ thesis Utrecht University, Budde Elinkwijk, Utrecht.

Slaa E.J. (2006) Population dynamics of a stingless bee community in the seasonal dry lowlands of Costa Rica, Insectes Soc. 53, 70-79.

Slaa E.J., Cevaal A., Sommeijer M.J. (1998) Floral constancy in Trigona stingless bees foraging on artificial flower patches: a comparative study, J. Apic. Res. 37, 191-198.

Slaa E.J., Wassenberg J., Biesmeijer J.C. (2003) The use of field-based social information in eusocial foragers: local enhancement among nestmates and heterospecifics in stingless bees, Ecol. Entomol. 28, 369-379.

Sofia S.H. (1996) As abelhas e suas visitas às flores em duas areas urbanas, $\mathrm{PhD}$ thesis Instituto de Biociências do campus de Rio Claro, Universidade Estadual Paulista, Brazil.

Taura H.M. (1990) A comunidade de abelhas silvestres (Hymenoptera, Apoidea) do Passeio Público, Curitiba, Paraná, Sul do Brasil: Uma abordagem comparativa, MSc thesis, Ciências Biológicas da Universidade Federal do Paraná, Brazil.

Viana B.F. (1992) Estudo da composição da fauna de Apidae e da flora da Chapada Diamantina, Lençóis - Bahia $\left(12^{\circ} 34^{\prime} \mathrm{S} / 41^{\circ} 23^{\prime} \mathrm{W}\right), \mathrm{MSc}$ thesis Instituto de Biociências da Universidade de São Paulo, Brazil.

Viana B.F. (1999) Biodiversidade da apifauna e flora apícola das dunas litorãneas da APA das Lagoas e Dunas de Abaeté, Salvador, Bahia - Composição, fenologia e suas interações, $\mathrm{PhD}$ thesis Instituto de Biociências da Universidade de São Paulo, Brazil.

Villanueva-G.R., Roubik D.W. (2004) Why are African Money bees and not European bees invasive? Pollen diet diversity in community experiment, Apidologie 35, 481-491.

Wilms W. (1995) Die Bienenfauna im Küstenregenwald Brasiliens und ihre Beziehungen zu Blütenpflanzen: Fallstudie Boracéia, São Paulo, $\mathrm{PhD}$ thesis, Fakultät für Biologie der Eberhard-Karls-Universität Tübingen, Germany.

Wilms W., Imperatriz-Fonseca V.L., Engels W. (1996) Resource partitioning between highly eusocial bees and possible impact of the introduced Africanized honey bee on native stingless bees in the Brazilian Atlantic Rainforest, Stud. Neotrop. Fauna Environ. 31, 137-151.

Wilms W., Wiechers B. (1997) Floral resource partitioning between native Melipona bees and the introduced Africanized honey bee in the Brazilian Atlantic rain forest, Apidologie 28, 339-355.

Zanella F.C.V. (1991) Estrutura da comunidade de abelhas silvestres (Hymenoptera, Apoidea) da ilha do mel, planicie litorânea paranaense, Sul do Brasil, com notas comparativas, MSc thesis, Ciências Biológicas da Universidade Federal do Paraná, Brazil. 